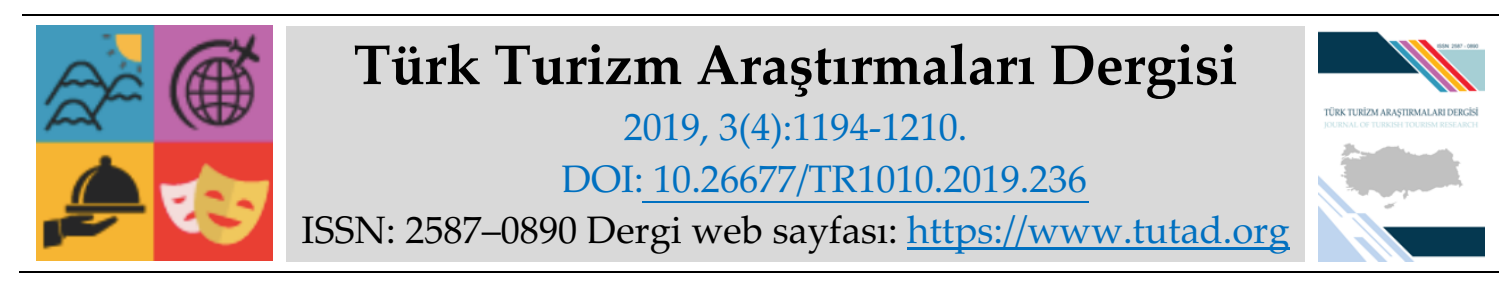

ARASTTIRMA MAKALESI

\title{
Rahatsızlık Endeksi Çerçevesinde Bodrum Sosyal Taşıma Kapasitesinin Belirlenmesi
}

Dr. Öğr. Üyesi Melahat YILDIRIM SAÇILIK, Bandırma Onyedi Eylül Üniversitesi, Erdek Meslek Yüksekokulu, e-posta: msacilik@bandirma.edu.tr ORCID: https://orcid.org/0000-0002-5399-8607

Öğr. Gör. Kadir BAYSAL, Muğla Sıtkı Koçman Üniversitesi, Marmaris Turizm Meslek Yüksekokulu, e-posta: kadirbaysal@mu.edu.tr ORCID: https://orcid.org/0000-0003-2652-6767

Öz

Sürdürülebilir kırsal turizm gelişimi için hazırlanan planların ve gerçekleştirilen faaliyetlerin yerel halk tarafından kabul görmesi, "sosyal taşıma kapasitesi" olarak adlandırılır ve yerel halkın destinasyonu ziyaret edenlerden etkilenmeme durumunu ve hoşgörü derecesini gösterir. Sosyal taşıma kapasitesinin belirli aralıklarla ölçülmesi, destinasyondaki turizm gelişiminde yerel halkın desteğinin belirlenmesi açısından büyük önem arz etmektedir. Bu nedenle çalışmanın amacı, turistler tarafından çoğunlukla tercih edilen Bodrum'un sosyal taşıma kapasitesini belirlemek ve Doxey'in rahatsızlık endeksi çerçevesinde turizm gelişiminden duyulan rahatsızlık seviyesini ortaya çıkarmaktır. Alan araştırmasında anket tekniği kullanılarak 365 katılımcı ile yüz yüze görüşmeler gerçekleştirilmiştir. Görüşmelerden elde edilen veriler, Yapısal Eşitlilik Modellemesi (YEM) aracılığıyla analiz edilerek kırsal turizmin gelişim aşamaları arasındaki ilişkiler irdelenmiştir. Analizler sonucunda Bodrum yerel halkının sosyal taşıma kapasitesi açısından iki ayrı düzeyde olduğu belirlenmiştir. "Aşırı iyi hissetme" düzeydeki katılımcılar, turizm gelişimine olumlu bakarken, "kayıtsızlı" düzeyindeki yerel halk Bodrum'daki turizm gelişimini, maddi getirisi ile istenenden çok mecbur olunan bir seçenek olarak görmektedir.

Anahtar Kelimeler: Bodrum, Rahatsızlık Endeksi, Sosyal Taşıma Kapasitesi, Turizm, Yapısal Eşitlilik Modellemesi.

Makale Gönderme Tarihi: 22.03.2019

Makale Kabul Tarihi: 01.10.2019

\section{Önerilen Atıf:}

Yıldırım Saçılık, M. ve Baysal, K. (2019). Rahatsızlık Endeksi Çerçevesinde Bodrum Sosyal Taşıma Kapasitesinin Belirlenmesi, Türk Turizm Araştırmaları Dergisi, 3(4): 1194-1210.

(C) 2019 Türk Turizm Araştırmaları Dergisi. 


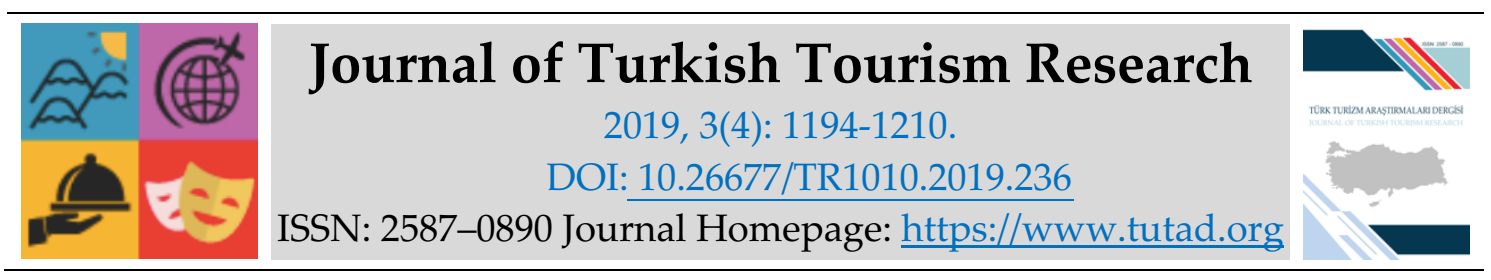

\title{
$\underline{\text { RESEARCH PAPER }}$
}

\section{Determination of Bodrum Social Carrying Capacity on the Discomfort Index Frame}

Dr. Melahat YILDIRIM SAÇILIK, Bandırma Onyedi Eylül University, Erdek Vocational School, e-mail:msacilik@bandirma.edu.tr ORCID: https://orcid.org/0000-0002-5399-8607

Lecturer, Kadir BAYSAL, Muğla Sıtkı Koçman University, Marmaris Tourism Vocational School, e-mail: kadirbaysal@mu.edu.tr ORCID: https://orcid.org/0000-0003-2652-6767

\begin{abstract}
The acceptance of the plans and activities carried out for the sustainable rural tourism development by the local population is called the social carrying capacity, and shows the level of unaffected and the degree of tolerance of local people. The measurement of social carrying capacity at specific intervals is of great importance in terms of determining the support of local people in tourism development in the destination. For this reason, the aim of the study is to determine the social carrying capacity of Bodrum which is preferred by tourists and to reveal the level of discomfort felt by tourism development within the framework of Doxey's discomfort index. Face to face interviews were conducted with 365 participants using the survey technique. The data obtained from the interviews were analyzed through Structural Equation Modeling (SEM) and the relationships between the stages of rural tourism development were examined. As a result of the analyzes, it has been determined that the local people of Bodrum have two levels in terms of their social carrying capacity. While the participants in the level of "Excessive feeling", looking at tourism development positively, other participants in the level of "Indigenous" see tourism development in Bodrum as an option that is more compulsory than it is required.
\end{abstract}

Keywords: Bodrum, Discomfort Index, Social Carrying Capacity, Tourism, Structural Equity Modeling.

Received: 22.03 .2019

Accepted: 01.10.2019

\section{Suggested Citation:}

Yıldırım Saçılık, M. and Baysal, K. (2019). Determination of Bodrum Social Carrying Capacity on the Discomfort Index Frame, Journal of Turkish Tourism Research, 3(4): 1194-1210.

(C) 2019 Türk Turizm Araştırmaları Dergisi. 


\section{Gíriş}

Bir bölgede yaşayan yerel halkın turizm gelişimini algılama aşamaları, doğrudan turizmin gelişim aşamaları olarak görülmektedir (İçöz vd., 2002). Turizmin gelişimine karşı yerel halkın tutumu, turizmden sağlanan fayda, genel memnuniyet algısı ile şekillenmektedir (Ko ve Stewart, 2002). Yerel halkın turizm gelişimine ilişkin tutumunda ele alınan değişkenler genellikle turizmin algılanan pozitif etkileri, turizmin algılanan negatif etkileri, turizm gelişiminden sağlanan kişisel fayda ve turizm gelişimine ilişkin memnuniyeti olarak değerlendirilir (Ekici ve Çizel, 2014). Bir bölgede turizmin sürdürülebilir k1lınabilmesi için planlanan turizmin gelişme şekli, ölçeği ve konumu ile ilgili olarak yöre toplumunun kabulünü kazanması gerekmektedir (Avcıkurt, 2003). Benzer şekilde, Jurowski vd., (1997) turizmin gelişebilmesi, sürdürülebilir kılınması ve başarıya ulaşabilmesi için yerel halkın desteğinin bir koşul olduğunu öne sürmüşlerdir. Yazarlara göre, yerel halkın turizme karşı tutumlarının nasıl geliştiği anlaşılmalı ve turizm gelişimiyle ilgili planlar buna göre yapılmalıdır. Duran ve Özkul (2012), turizm gelişiminin sağlanması ve sürdürülebilir kılınması için yerel halkın turist ve turizm algısının belirlenmesi, farkındalığının ve desteğinin alınması (gelişim sürecine katılımını sağlayacak bilgi, farkındalık ve desteğinin sağlanması) önemli bir konu olduğunu savunmaktadırlar. Turizm gelişimi ve yerel halk davranışlarını açıklayan bir teori olan Sosyal Değişim teorisinde yerel halkın turizm gelişimine olan desteğinin, turizme yönelik algıladıkları faydanın, turizmin neden olduğu maliyeti geçmediği sürece devam edebilmektedir (Allen vd., 1993; Jurowski vd., 1997).

Turizmin söz konusu etkilerinin olumlu yönde yüksek oranlara çıkarılması için yerel halkın ilgisine, bilgisine, desteğine ihtiyaç vardır. Avcıkurt'a (2003) göre yerel halkı turizm gelişim sürecine dâhil etmek, onların bu konudaki görüş ve önerilerini almak, fikir alışverişinde bulunmak ve gelecekteki turizm gelişmesini teşvik yönünde karşllkklı fikir alışverişi yapmak yerel halkın karar merkezlerini etkileyebilmesi ve kendilerini turizmin bir parçası olarak hissetmeleri açısından oldukça önemlidir. Turizm gelişmelerinde yerel halkın ilgisinin eksikliği turizmin yararlarının düzensiz dağılımına yol açan önemli bir sorundur (Sekhar, 2003). Gunn (1988) yerel halkın fikir ve görüşlerinin alınmadığı durumunda turizmin geliştirilmesi ve turizm gelirlerinin artırılması veya diğer bir ifadeyle sürdürülebilir bir turizm gelişim modelinin hayata geçirilmesinin imkânsız olduğunu belirtmiştir. Çünkü yerel toplumun değerleri ve beklentileri dikkate alınmadan yapılan salt ekonomik planlama yaklaşımlarının başarılı olamayacağı kanısındadır. Bununla birlikte yazar, destinasyonlarda sürdürülebilir turizm şeklinin gerçekleşebilmesi ve olumlu etkilerin en üst düzeye çıkarılması için planlama çalışmalarına yerel halkın mutlaka dâhil edilmesi ve onların görüş ve önerileri doğrultusunda şekillenmesinin sağlanması gerekliliği üzerinde önemle durmaktadır. Jurowski vd. (1997), turizm endüstrisinin gelişiminde istenilen başarıya ulaşabilmek için yerel halkın turizme karşı tutumlarının nasıl geliştiğinin anlaşılması ve turizm gelişimiyle ilgili planların buna göre yapılmasının önemini vurgulamaktadırlar. Yerel halkın turizme katılımının söz konusu olmadığı durumlarda destinasyonlardaki turizm faaliyetlerinin planlanması ve uygulanması başarısızlıkla sonuçlanır. Böyle bir sorunun yaşanmaması için başta Doxey (1975) olmakla birlikte Knopp (1980), Maddox (1985), Allen vd., (1988); Davis vd., (1988); Long ve Richarden (1989) gibi araştırmacılar yerel halkın turizme dair tutum ve algılarının sürekli çalışılması gereken bir konu olduğunu öne sürmüşlerdir.

Turizmin yerel halk üzerindeki etkilerinin belirlenmesinde temel alınan unsur turistik bölgenin taşıma kapasitesidir. Taşıma kapasitesi fiziksel, ekolojik, çevresel ve sosyal olarak sınıflandırılmaktadır (Sowman, 1987). Bu çalışmada amaca yönelik olarak turistik taşıma kapasitesi ve özellikle turizm gelişiminde etkilenen ve etkileyen yerel halkın tutumlarının ele alındığı Bodrum destinasyonunun sosyal taşıma kapasitesi irdelenmiştir. Bodrum ilçesi, her yıl taşıma kapasitesinin çok üzerinde bir doluluk yaşamaktadır. Turizm gelişiminin olumlu ve 
olumsuz tüm fiziksel, ekolojik, çevresel ve sosyal etkilerini halk üzerinde görmek mümkün olsa da turizmin Bodrum'da bu denli yoğun yaşanmasının nedenlerinin ortaya konulması gerekmektedir. Turizmin etkilerinin belirlendiği bu tür çalışmalar, belirli aralıklarla tekrarlanması gereken çalışmalardır. Literatürde sıklıkla yer alan taşıma kapasitesi çalışmaları, turizmin gelişiminin yarattığı etkilerinin, zaman içerisindeki değişimini görmek için büyük önem arz etmektedir. Destinasyondaki turizm faaliyetlerinin planlanması ve arz - talep ilişkisinin stratejik düzenlemesinin yapılması açısından turizm gelişimini etkileyen ve aynı zamanda turizm gelişiminden etkilenen yerel halkın tutumunun belli aralıklarla ölçülmesi gerekmektedir. Literatür incelemesinde Bodrum için yapılan tutum belirlemesi çalışmalarına rastlanamamıştır. Bu yüzden Bodrum için yapılan bu çalışmanın birkaç yıl sonra tekrarlanması ve yerel halkın tutumundaki değişimin belirlenmesi zorunluluk haline gelmiştir.

\section{KAVRAMSAL ÇERÇEVE}

\section{Taşıma Kapasitesi}

Turizm alanlarının taşıma kapasitesi, turizmin etkilerinin belirlenmesinde ve anlaşılmasında büyük önem taşımaktadır. Aynı zamanda destinasyonların planlanması ve turizm faaliyetlerinin düzenlenmesi açısından da taşıma kapasitesi büyük öneme sahip olmaktadır (Avcl, 2007). Turizm açısından "taşıma kapasitesi" bir bölgenin o bölge doğal kaynaklarına, o bölgenin halkına, ekonomisine ve kültürüne olumsuz etki yaratmadan ve ziyaretçilerin tatmin seviyesini azaltmadan maksimum seviyede kullanılmasını belirleyen seviyedir (Can, 2013). Turizm taşıma kapasitesi iki bakış altında ele alınmaktadır.

Birinci bakış açısına göre turizm taşıma kapasitesi, turizmin olumsuz etkilerinin yerel halk tarafından hissedilmediği durum olup destinasyondaki yerel halkın turizmin karşılama gücünü ifade etmektedir. Bu bakış açısı, turizmin taşıma kapasitesi ne kadar turist çekebilmesinin değil ne kadar turist istendiğinin göstergesidir. İkinci bakış açısının odak noktasında turistler yer almaktadır. Bir çekim yerinin turistleri doygunluğa ulaştırması ve turistlerin başka çekim yerleri aramasına neden olmaktadır (Rızaoğlu, 1997). Taşıma kapasitesi, bazı yazarlar tarafından belli sınıflara ayrılmıştır. Genel olarak turizm taşıma kapasitesi ile ilgili dört ayrı sınıflandırma yapılmaktadır. Bunlar; ekolojik, fiziksel, ekonomik ve toplumsal taşıma kapasiteleridir. (Hall 2001). Sowman (1987) destinasyon taşıma kapasitesini ekolojik, çevresel, fiziksel ve sosyal taşıma kapasitesi olarak dört sınıfta ele almıştır. Rızaoğlu (1997) taşıma kapasitesini ortamsal, algısal, ekonomik ve toplumsal olarak sınıflandırmıştır.

\section{Sosyal Taşıma Kapasitesi}

Turistik deneyimin sonucunda elde edilen tatmin veya memnunluğun en alt seviyesini belirleyen bir kavram olan sosyal taşıma kapasitesi algısal, psikolojik veya davranışsal ve toplumsal kapasite olarak ifade edilmektedir. Yerel halkın gelen ziyaretçilerden etkilenmeme düzeyi olarak ifade edilen sosyal taşıma kapasitesi aynı zamanda, yerel halkın turistlerin varlığına karşı gösterdiği hoşgörü derecesi olarak da kabul edilmektedir (Avcl, 2007). Yerel halkın turizm gelişiminde edindiği tutum, Doxey (1975)'in "Rahatsızlık Endeksi" çalışmasında ayrıntılı olarak ele alınmıştır. Yazar bu çalışmada turizm bölgelerinin aşırı iyi hissetme durumundan, kayıtsızlık, rahatsızlık, muhalefet ve son düzeye kadar aşamalı bir süreç yaşadığını belirtmiştir. Çalışmaya göre, bölge halkının turizm gelişimine olumlu baktığı ve turistleri iyi karşıladığı "Aşırı İyi Hissetme Düzeyi" döneminde yerel halk, turizmin maddi getirisinin ön planda tutmakta ve algılamaktadır. Turizmin maddi getirisinin istenenden çok bir mecburiyet olduğu kanısı "Kayıtsızlık Düzeyi" 
döneminde yaşanmaktadır. Turizm bölgesindeki turizm gelişiminden ve turist hareketlerinden rahatsızlık duyulan süreç "Rahatsızlık Düzeyi” dönemidir. Bu rahatsızlığın belirgin bir hal aldığı süreç ise "Muhalefet Düzeyi" olarak belirtilmektedir. Rahatsızlık endeksinin son süreci olan "Son Düzey" yerel halkın, turizm gelişiminin yol açtığı çevresel bozulmalara ve kirliliğe çözüm bulunamayacağı ve bazı değerlerin yitirilmiş olduğunu anlaması ile başlamaktadır (aktaran: Kahraman ve Türkay, 2006). Sosyal taşıma kapasitesi, yerel halkın turizm gelişimine karşı gösterdiği hoşgörü sınırı olduğunu belirten Rızaoğlu (1997), bu sınırın aşılmasının çekim yerindeki turistik faaliyetlerin, çekiciliği azalmasında etkili olabileceği kanısındadır. Aynı zamanda yazara göre sosyal taşıma kapasitesi aşımı, yerel halkın sosyal ve kültürel amaçlarını yaşayabilirliğini tehdit eden sorunlara yol açması mümkündür. Bu tehdidin aşılması için yapılması gereken en önemli işin planlama doğrultusunda turizmin gelişimini sağlamaktır. Can (2013) taşıma kapasitesinin aşılmaması, turistin memnuniyeti ve destinasyonun sosyal yaşamının normal düzeyde devamı için de önemlidir.

Turizm gelişiminde kişisel fayda sağlamaya yönelik çalışmalar arasında Getz (1994)'in İskoçya Spey Vadisi yerel halkın üzerinde yaptığı çalışma yer almaktadır. Bu çalışmada yazar turizmin negatif etkilerine maruz kalan halkın, turizmden beklediği faydayı sağlayamadığını ortaya çıarmıştır. Bunun aksine Vargas ve Sanches (2009), 2009 yılında İspanya Huelva yerel halkının turizmin pozitif etkilerinden etkilenmelerinden dolayı turizmden kişisel fayda sağlayabildiklerini ve bununla birlikte turizm gelişiminden memnuniyet seviyelerinin yüksek olduğu belirtmişlerdir. Vesey ve Dimanche (2000), yerel halk tutumları ile ekonomik bağımlılık arasında ilişki belirledikleri çalışmalarında turizmden gelir elde eden yerel halkın, turizme ve turizm gelişim sürecine yönelik daha olumlu bir algıya sahip oldukları ve bu sürece aktif olarak destek vermeye çalıştıkları görülmüştür. Turizm gelişiminden yerel halk memnuniyeti üzerine yapılan çalışmalardan biri olan Ko ve Stewart (2002), Kore yerel halkının turizm gelişimine karşı algılarının pozitif yönde geliştiği ve yerel halkın yöredeki turizm gelişiminde memnun oldukları sonucuna varmışlardır. Çalışkan ve Özer (2014) tarafından Kuşadası yerel halkının turizme karşı tutumunun incelendiği çalışmada, turizm planlamasında yerel halk ile sosyal ve çevresel ihtiyaçlara ekonomik konular kadar önem verilmediği ortaya çıkmıştır. Bunun yanında, turizm gelişiminden mutluluk düzeyleri ile bağımsız değişkenler arasında önemli bir ilişki olduğu da belirlenen sonuçlar arasındadır.

Duran (2013), Bozcaada yerel halkı sürdürülebilir turizm gelişimine yönelik tutumlarının belirlendiği çalışmada, yerel halk desteğinin tüm yapılardan özellikle "turizmden fayda sağlama" ve "uzun dönem planlama" faktörleri arasındaki ilişki düzeyinden yüksek oranda etkilendiğini belirlemiştir. Ekici ve Çizel (2014), yerel halkın turizm gelişimi desteğine ilişkin tutumlarının, destinasyonların gelişme düzeylerine göre farklılıklarını ele almışlar ve ManavgatSerik ve Kaş-Kalkan yerel halklarının tutumlarında destinasyon gelişme aşamasına göre farklılaştığını belirlemişlerdir. Gelişme aşamasında olan Manavgat-Serik yerel halkının turizm gelişimine yönelik pozitif etkileri algısı yüksek iken, gerileme aşamasında olan Kaş-Kalkan yerel halkının turizmin negatif etkileri algısının yüksek olduğu saptanmıştır. Negatif etkinin yüksek olması, yerel halkın turizm gelişimine ilişkin memnuniyet düzeylerine ve turizm gelişimi desteğine ilişkin tutumlarına olumsuz yansımıştır. Bunun yanında her iki bölge halkının turizm gelişiminden sağladıkları fayda algısının yükselmesi ile birlikte, memnuniyet düzeylerinin de yükseldiği görülmüştür. Zhong vd. (2011)'un yine Çin' de gerçekleştirdiği çalışmasında, turizmin özellikle sosyal ve doğal çevre üzerindeki olumsuz etkilerine vurgu yaparken, bu etkilerin azaltılabilmesi için taşıma kapasitesi kavramının göz önünde bulundurulması gerektiğini ifade etmişlerdir. 


\section{YÖNTEM}

\section{Araştırmanın Amacı}

Çalışmanın amacını Bodrum yerel halkının turizm gelişimindeki desteğine ilişkin tutumlarının belirlenmesi oluşturmaktadır. Amaca yönelik olarak bu çalışmada turizm gelişimine ilişkin ele alınan turizmin algılanan pozitif etkileri, turizmin algılanan negatif etkileri, turizm gelişiminden kişisel fayda sağlama ve turizm gelişimine ilişkin memnuniyet değişkenlerinin aralarındaki ilişki belirlenmeye çalışılmıştır.

\section{Araştırmanın Örneklemi}

Araştırmanın evreni olarak Türkiye'de önemli bir turistik destinasyon olan Bodrum yerel halkı seçilmiştir. Faktör analizi yapılacak çalışmalarda örneklem büyüklüğü, anket ifade sayısına göre belirlenmektedir. Faktör analizinde ilişkilerin güvenilir bir şekilde gösterilmesi için örneklemin uygun büyüklükle olması önemlidir. Literatürde, değişken sayısı fazla büyük olmadığında, faktörler güçlü ve belirgin olduğunda 100 ile 200 arasındaki örneklem büyüklügünün yeterli olduğu belirtilmektedir (Büyüköztürk, 2002). Genel bir kurala göre, çalışma grubunu faktör analizi tekniğinin kullanımı için önerilen madde sayısı veya gözlenen değişken sayısının beş katı örneklem büyüklügü olması gerektiği ifade edilmektedir (Child, 2006).

Yukarıdaki bilgiye göre 29 ifadeden oluşan anket uygulamasında $145(29 * 5)$ katılımcıdan oluşan bir örneklem yeterli olmaktadır. Çalışmanın örneklemini Bodrum'da yaşayan 365 adet yerel halk oluşturmaktadır. Araştırma verilerinin toplanması için 2018 yılı Nisan - Temmuz ayları arasında Bodrum'da turizmin yoğun olduğu ve dolayısıyla turizmin tüm fiziksel, ekolojik, çevresel ve sosyal etkilerinin yerel halk tarafından daha fazla hissedildiği dönem seçilmiştir.

\section{Veri Toplama ve Analiz Yöntemi}

Araştırmada veri elde etmek için anket yöntemi kullanılmıştır. Ankette kullanılan ölçekte Ekici ve Çizel (2014) tarafından derlenen "Yerel halkın turizm gelişimi desteğine ilişkin tutum ölçeği kullanılmıştır. Anket iki bölümden oluşmaktadır. Ankette kullanılan ölçeğin birinci bölümünde turizm gelişiminden algılanan pozitif ve negatif etkiler, turizm gelişiminden sağlanan fayda ve memnuniyet, turizm gelişim tutumuna ilişkin 21 adet açı uçlu soru bulunmaktadır. İkinci bölümde ise katılımcıların demografik özelliklerine ilişkin sorular yer almaktadır. Çalışmanın alan araştırmasından elde edilen veriler YEM (Yapısal Eşitlik Modeli) ile analiz edilmiştir. Yapısal Eşitlilik Modellemesi (YEM) aracılığıyla model oluşturulmuş ve "yerel halkın turizm gelişim desteğine ilişkin yerel halk tutumu", "turizmin algılanan pozitif etkileri", "turizmin algılanan negatif etkileri" "turizm gelişiminden kişisel fayda sağlama" ve "turizm gelişimine ilişkin yerel halk memnuniyeti", boyutları arasındaki ilişkiler irdelenmiştir. Analiz aşamasında aşağıdaki hipotezler test edilmiştir.

H1: Turizm gelişiminden sağlanan kişisel fayda boyutunun yerel halkın turizm gelişimine ilişkin memnuniyet düzeyi boyutu üzerinde anlamlı bir etkisi vardır.

H2: Turizm gelişiminden sağlanan kişisel fayda boyutunun yerel halkın turizm gelişimine ilişkin desteği boyutu üzerinde anlamlı bir etkisi vardır. 
H3: Turizmin algilanan pozitif etkileri boyutunun yerel halkın turizm gelişimine ilişkin memnuniyet düzeyi boyutu üzerinde anlamlı bir etkisi vardır.

H4: Turizmin algılanan pozitif etkileri boyutunun yerel halkın turizm gelişimine ilişkin desteği boyutu üzerinde anlamlı etkisi vardır.

H5: Turizmin algılanan negatif etkileri boyutunun yerel halkın turizm gelişimine ilişkin memnuniyet düzeyi boyutu üzerinde anlamlı bir etkisi vardır.

H6: Turizmin algilanan negatif etkileri boyutunun, yerel halkın turizm gelişim desteğine ilişkin desteği boyutu üzerinde anlamlı bir etkisi vardır.

H7: Yerel halkın turizm gelişimine ilişkin memnuniyet düzeyi boyutunun, yerel halkın turizm gelişimine ilişkin desteği boyutu üzerinde anlamlı bir etkisi vardır.

\section{ANALIZ ve BULGULAR}

Çalışmanın bu bölümünde katılımcıların demografik özelliklerine, açımlayıcı ve doğrulayıcı faktör analizi bulgularına, boyutlar arasındaki ilişkilerinin belirlendiği ölçüm modeline, yol katsayılarına ve hipotez sonuçlarına yer verilmiştir.

\section{Demografik Özelliklere İlişkin Bulgular}

Örneklem dâhilinde araştırmaya katılan katılımcıların demografik özellikleri belirlenmiştir (Tablo 1). Buna göre birbirine yakın oranlarda kadın ve erkek katılımcıyla görüşülmüştür. Alan araştırmasında veri elde edilmeye çalışılırken hemen her yaş grubundaki katılımcılardan görüş alınmaya çalışılmıştır. Katılımcıların \%60,5'i 45 yaş altındadır. Bu, Bodrum'da dinamik bir yapı varlığının bir göstergesidir. Literatür araştırmasında sıklıkla kişilerin eğitim düzeyleri ile tatil alg1sı, yeni yerler görme isteği ve turizm algısı arasında doğru orantılı bir anlamlılık bulunduğu görülmüştür. Araştırmadan elde edilen bulgulara göre katılımcıların \%46,8'i ön lisans-lisans ve lisansüstü eğitim seviyesine sahiptir. Her meslek grubundan kişiyle görüşme gerçekleştirilen bu çalışmada öğretmen, hizmet personeli, emekli ve öğrenci gruplarının çoğunlukta olduğu görülmüştür.

Emekli 'ye (2001) göre kamu ve özel sektör üst çalışanlarının serbest meslek sahibi, öğretmen ve öğrenciler turizme daha fazla katılmaktadır. İşçi ve çalışanların yeterli geliri ve zamanı olmadığı için turizme daha fazla katılamamalarının yanı sıra, tatil alışkanlıkları da olmamaktadır. Analiz bulguları sonuçları da bu kanıyı doğrular niteliktedir. Aynı zamanda eğitim seviyesi arttıkça gelir seviyesinin arttığ düşüncesi, turizme katılma oranının fazlalığına işarettir. Katılımclara yöneltilen aile geliri ve değerlendirme şekline ait soruların amacı, Bodrum turizminin geleceği için yerel halkın gelirinin nasıl olduğu ve nasıl değerlendirdiğinin tespitidir. Araştırmaya katılanların yarısından fazlası gelirlerini diğer (borç ödemede, vb.) amaçlar için kullanmaktadırlar. Geriye kalan katılımcılar gelirlerini çoğunlukla bankada, gayrimenkul alımında değerlendirmektedir. Daha düşük oranlarda döviz alımı, yapılan işi büyütme ve toprak alımı gerçekleşmektedir. 
Tablo 1: Katılımcıların Demografik Özellikleri

\begin{tabular}{|c|c|c|c|c|c|}
\hline Cinsiyet $(n=365, ; \% 100)$ & $\mathbf{n}$ & $\%$ & M. Durum $(n=364 ; 99,7)$ & $\mathbf{n}$ & $\%$ \\
\hline Kadın & 163 & 44,7 & Evli & 204 & 55,9 \\
\hline \multirow[t]{2}{*}{ Erkek } & \multirow[t]{2}{*}{202} & \multirow[t]{2}{*}{55,3} & Bekâr & 160 & 43,8 \\
\hline & & & Yanitsiz & 1 & 0,3 \\
\hline Yaş (n=364; \% 99,7) & $\mathbf{n}$ & $\%$ & Meslek $(n=346 ; \% 94,8)$ & $\mathbf{n}$ & $\%$ \\
\hline $35-44$ & 111 & 30,4 & Hizmet Personeli & 69 & 18,9 \\
\hline $25-34$ & 110 & 30,1 & Esnaf & 53 & 14,5 \\
\hline $45-54$ & 60 & 16,4 & İşçi & 47 & 12,9 \\
\hline $15-24$ & 55 & 15,1 & Memur & 27 & 7,4 \\
\hline $55-64$ & 21 & 5,8 & Yönetici & 25 & 6,8 \\
\hline 65 ve üstü & 7 & 1,9 & Emekli & 19 & 5,2 \\
\hline Yanitsiz & 1 & 0,3 & Ev Hanımı & 14 & 3,8 \\
\hline Eğ.Durumu (n= $365 ; \%$ 100) & $\mathbf{n}$ & $\%$ & Öğretmen & 12 & 3,3 \\
\hline Önlisans/Lisans & 171 & 46,8 & Akademisyen & 10 & 2,7 \\
\hline Lise & 136 & 37,3 & Mühendis & 6 & 1,6 \\
\hline İlköğretim & 34 & 9,3 & Mimar & 3 & 0,8 \\
\hline & 24 & 66 & Diğger & 61 & 16,7 \\
\hline Lisansüstü & & 0,0 & Yanitsiz & 19 & 5,2 \\
\hline $\begin{array}{l}\text { Aile Aylık Gelir } \\
(\mathrm{n}=365 ; \% 100)\end{array}$ & $\mathbf{n}$ & $\%$ & $\begin{array}{l}\text { Aile Gelirini Değerlendirme } \\
\text { Şekli }(n=364 ; \% 99,7)\end{array}$ & $\mathbf{n}$ & $\%$ \\
\hline $2,000-3,500 \mathrm{TL}$ & 132 & 36,2 & Borç Ödeme & 164 & 44,9 \\
\hline 2000 TL'den az & 97 & 26,6 & Bankaya Yatırma & 74 & 20,3 \\
\hline 3,501 - 5,000 TL & 77 & 21,1 & Yapılan İşi Büyütme & 39 & 10,7 \\
\hline $5,001-7,500 \mathrm{TL}$ & 34 & 9,3 & Toprak Alımı & 31 & 8,5 \\
\hline 7,500 TL'den fazla & 25 & 6,8 & Döviz-Altın Alımı & 30 & 8,2 \\
\hline & & & Gayrimenkul Alımı & 26 & 7,1 \\
\hline & & & Yanitsiz & 1 & 0,3 \\
\hline
\end{tabular}

\section{Açıklayıcı Faktör Analizine İlişkin Bulgular}

Çalışmanın bu aşamasında açıklayıcı faktör analizinin uygulanabilirliğinin ölçümü için, KMO (Kaiser-Meyer-Olkin) ve Bartlett testlerinin analizleri yapılmıştır ve örneklem yeterliliğini temsil eden KMO oranı 0,837 olarak belirlenmiştir. Dolayısıyla, bu çalışmada ele alınan örneklem büyüklügüüün faktör analizi için uygun olduğu görülmüştür. Açımlayıcı faktör analizinin gerçekleştirilmesinde temel bileşenler yöntemi tercih edilmiştir. Veri derleme aracının faktör yapısını görmek için verilere dik (orthogonal) döndürme yöntemlerinden biri olan "Varimax" döndürme işlemi uygulanmıştır. 21 madde ile başlanılan faktör analizi sonucunda, ortak varyans değerleri olduğu görülmüş ve 21 maddenin oluşturduğu 5 faktörlü bir yapıyla daha sonraki analizler gerçekleştirilmiştir. Analiz sonucunda elde edilen ortak varyans değerleri ve maddeler için Cronbach Alpha iç tutarlılık katsayıları Tablo 2'de gösterilmektedir.

Açımlayıcı faktör analizi sonucuna göre, araştırma modelinin 5 gizil değişkeni bulunmaktadır. Modelin 5 gizil değişkeninden ikisi endojen-gizil değişken, diğer üçü egzojen-gizil değişkenlerdir. Modeldeki endojen-gizil değişkenler (bağımlı değişken) "Yerel Halk Memnuniyeti" ve "Yerel Halk Tutumu" değişkenleridir. İki endojen-gizil değişkene etki eden egzojen-gizil değişkenler ise "Pozitif Algı", "Kişisel Fayda", "Negatif Alg1" değişkenleridir. 21 madde ve 5 boyuttan oluşan yapıyı doğrulamak amaciyla kurulan model IBM AMOS 22 programı aracılı̆̆ıyla analiz edilmiştir. Model için "En Çok Olabilirlik (Maximum Likelihood)" yöntemi kullanılmıştır. Modeli test etmek için yapılan doğrulayıcı faktör analizi sonucunda elde edilen uyum değerleri Tablo 3'de gösterilmektedir. 
Tablo 2: Açıklayıcı Faktör Analizi

\begin{tabular}{|c|c|c|c|}
\hline $\begin{array}{l}\text { Kaiser-Meyer-Olkin Ölçek Geçerlilik: 0,837 } \\
\text { Bartlett's Küresellik Testi Ki Kare: } 3245,940\end{array}$ & \multirow{2}{*}{$\begin{array}{l}\text { Faktör } \\
\text { Yükü } \\
\%\end{array}$} & \multirow{2}{*}{$\begin{array}{c}\text { Ortak } \\
\text { Varyans }\end{array}$} & \multirow{2}{*}{$\begin{array}{l}\text { Güven } \\
\text { ilirlik }\end{array}$} \\
\hline Turizmin Algılanan Pozitif Etkileri & & & \\
\hline $\begin{array}{l}\text { PA1: Turizm, yerel halkın kültürel gelişimine katkı sağlamaktadır. } \\
\text { PA2: Turizm, yerel halkın yaşam kalitesini arttırmaktadır. } \\
\text { PA3: Turizm, yerel halka ekonomik kazanç sağlamaktadır. } \\
\text { PA4: Turizm, doğayı, tarihi ve kültürel değerleri koruyan bir faaliyettir. } \\
\text { PA5: Turizm, doğal çevrenin korunmasına ve gelişimine katkıda bulunmaktadır. }\end{array}$ & $\begin{array}{l}0,793 \\
0,763 \\
0,558 \\
0,742 \\
0,732 \\
\end{array}$ & \multirow[t]{2}{*}{75,166} & \multirow[t]{2}{*}{0,766} \\
\hline Turizmin Algılanan Negatif Etkileri & & & \\
\hline $\begin{array}{l}\text { NA3: Turizm, aşırı kalabalıklaşma, gürültü, trafik gibi sorunlar yaratmaktadır. } \\
\text { NA4: Turizm gelişimi, çevresel kirliliğe neden olmaktadır. } \\
\text { NA2: Turizm, yerel halkın kültürel değerlerinin yok olmasına neden olmaktadır. } \\
\text { NA1: Turizm, yerel halkın tutum ve davranışlarını olumsuz etkilemektedir. } \\
\text { NA5: Turizm yörede hayat pahalılığına neden olmaktadır. } \\
\text { NA4: Turizm gelişimi, çevresel kirliliğe neden olmaktadır. }\end{array}$ & $\begin{array}{l}0,851 \\
0,818 \\
0,805 \\
0,736 \\
0,705 \\
0,797 \\
\end{array}$ & \multirow[t]{2}{*}{61,705} & \multirow[t]{2}{*}{0,843} \\
\hline Turizm Gelişiminden Kişisel Fayda Sağlama & & & \\
\hline $\begin{array}{l}\text { F2: Turizm gelişimi, benim işimi olumlu yönde etkilemektedir. } \\
\text { F3: Yörede turizm olmazsa işlerim çok azalır. } \\
\text { F1: Yöredeki turizm gelişiminden genel olarak ben de faydalanmaktayım. } \\
\text { Turizm Gelişimine İliskin Yerel Halk Memnuniyeti }\end{array}$ & $\begin{array}{l}0,928 \\
0,878 \\
0,857 \\
\end{array}$ & 78,870 & 0,863 \\
\hline $\begin{array}{l}\text { M4: Turizmin yöremize sağladığı sosyal imkân ve olanaklardan memnunum. } \\
\text { M3: Turizmin yöremize sağladığı ekonomik gelişmelerden memnunum. } \\
\text { M1: Turizm ile birlikte gelişen kamu hizmetlerinden memnunum. } \\
\text { M2: Turizmin yaratmış olduğu çevresel değişim ve gelişimden memnunum. }\end{array}$ & $\begin{array}{l}0,828 \\
0,807 \\
0,796 \\
0,778 \\
\end{array}$ & \multirow[t]{2}{*}{64,226} & \multirow[t]{2}{*}{0,813} \\
\hline Turizm Gelişim Desteğine İlişkin Yerel Halk Tutumu & & & \\
\hline $\begin{array}{l}\text { D3: Yörede, turizmin daha fazla gelişimi için çaba sarf edilmelidir. } \\
\text { D2: Yörede, turizm yatırımları artarak devam etmelidir. } \\
\text { D4: Yöredeki turizm gelişimini destekliyorum. } \\
\text { D1: Turizm, toplumumuzun önemli bir parçası olmaya devam etmelidir. }\end{array}$ & $\begin{array}{l}0,874 \\
0,854 \\
0,815 \\
0,760\end{array}$ & 68,394 & 0,845 \\
\hline TOPLAM & & 71,293 & 0,744 \\
\hline
\end{tabular}

Tablo 3: Model Uyum Değerleri

\begin{tabular}{|l|c|c|}
\hline & Değerler & Kabul Edilebilir Uyum \\
\hline$X^{2}$ & 304,348 & - \\
Serbestlik Derecesi & 146 & - \\
$\mathbf{P}$ & 0,000 & - \\
X'/df & 2,085 & $<3$ \\
TLI & 0,931 & $>0,90$ \\
CFI & 0,947 & $>0,90$ \\
NFI & 0,905 & $>0,90$ \\
IFI & 0,948 & $>0,90$ \\
RMSEA & 0,059 & $\leq 0,08$ \\
SRMR & 0,049 & $<0,10$ \\
\hline
\end{tabular}

Tablo 3'e göre modelin kabul edilebilir uyum değerlerine sahip olduğu görülmüştür. Buna dayanarak modeldeki değişkenlerin faktör yük değerleri (standardize edilmiş regresyon katsayıları), standart hataları, t değerleri (anlamlılık), CR ve AVE değerleri hesaplanmıştır (Tablo 4). Faktör yük değerleri ya da diğer bir adıyla standardize edilmiş regresyon katsayıları, her bir gözlenen değişken ile ilgili olduğu gizil değişken arasındaki korelasyonları göstermektedir. Standardize edilmiş regresyon katsayılarının 0,522 ile 0,881 arasında değer aldığı görülmektedir. Gözlenen değişkenlerin ilgili oldukları gizil değişken tarafından anlamlı olup olmadığına ilişkin 
t değerlerine bakıldığında, tüm gözlenen değişkenlere ait $t$ değerlerinin 1,96 ' dan büyük olduğu görülmektedir.

Bileşik güvenilirlik (CR) değerinin 0.70 ve üzerinde bir değer alması, gizil yapı göstergelerinin güvenilir ve aynı yapıyı ölçtüğünün bir göstergesidir. CR değerleri, "turizmin algılanan pozitif etkileri" boyutu için 0,897; "turizmin algılanan negatif etkileri" boyutu için 0,881; "turizm gelişiminden kişisel fayda sağlama" boyutu için 0,702; "yerel halkın turizm gelişimine ilişkin memnuniyet düzeyi" boyutu için 0,849 ve "yerel halkın turizm gelişimine ilişkin desteği" boyutu için 0,857 olarak hesaplanmıştır. Bu değerlerin, kabul edilebilir değer olan 0,70'in üzerinde olduğu görülmektedir. İlgili gizil yapı için hesaplanan göstergelerdeki toplam varyansın açılanmasıyla hesaplanabilen açıklanan ortalama varyans (AVE) değeri de bileşik güvenilirliğin tamamlayıcı bir unsurudur (Yoon, 2002: 102). AVE değerinin 0,50 ve üzerinde bir değer alması gerekmektedir (Yoon, 2002). AVE değerleri, "turizmin algılanan pozitif etkileri" boyutu için 0,686; "turizmin algilanan negatif etkileri" boyutu için 0,597; "turizm gelişiminden kişisel fayda sağlama" boyutu için 0,875; "yerel halkın turizm gelişimine ilişkin memnuniyet düzeyi" boyutu için 0,586 ve "yerel halkın turizm gelişimine ilişkin desteği" boyutu için 0,602 olarak hesaplanmıştır.

Tablo 4. Ölçüm Modeline İlişkin Değerler

\begin{tabular}{|c|c|c|c|}
\hline & SRK & SH & $\mathbf{T}$ \\
\hline \multicolumn{4}{|c|}{ Turizmin Algılanan Pozitif Etkileri (Bileşik Güvenilirlik-CR: 0,897; Açıklanan Ortalama Varyans-AVE:0,686) } \\
\hline $\begin{array}{l}\text { PA5: Turizm, doğal çevrenin korunmasına ve gelişimine katkıda bulunmaktadır. } \\
\text { PA4: Turizm, doğayı, tarihi ve kültürel değerleri koruyan bir faaliyettir. } \\
\text { PA2: Turizm, yerel halkın yaşam kalitesini artırmaktadır. } \\
\text { PA1: Turizm, yerel halkın kültürel gelişimine katkı sağlamaktadır. }\end{array}$ & $\begin{array}{l}0,656 \\
0,689 \\
0,569 \\
0,584\end{array}$ & $\begin{array}{l}- \\
0,080 \\
0,111 \\
0,118\end{array}$ & $\begin{array}{c}- \\
12,071 \\
6,447 \\
6,657\end{array}$ \\
\hline \multicolumn{4}{|c|}{ Turizmin Algılanan Negatif Etkileri (Bileşik Güvenilirlik-CR: 0,881; Açıklanan Ortalama Varyans-AVE:0,597) } \\
\hline $\begin{array}{l}\text { NA5: Turizm yörede hayat pahalılığına neden olmaktadır. } \\
\text { NA4: Turizm gelişimi, çevresel kirliliğe neden olmaktadır. } \\
\text { NA3: Turizm, aşırı kalabalıklaşma, gürültü, trafik gibi sorunlar yaratmaktadır. } \\
\text { NA2: Turizm, yerel halkın kültürel değerlerinin yok olmasına neden olmaktadır. } \\
\text { NA1: Turizm, yerel halkın tutum ve davranışlarını olumsuz etkilemektedir. }\end{array}$ & $\begin{array}{l}0,663 \\
0,830 \\
0,881 \\
0,635 \\
0,522 \\
\end{array}$ & $\begin{array}{l}- \\
0,121 \\
0,133 \\
0,096 \\
0,096\end{array}$ & $\begin{array}{c}- \\
9,866 \\
10,260 \\
10,041 \\
8,084\end{array}$ \\
\hline \multicolumn{4}{|c|}{$\begin{array}{l}\text { Turizm Gelişiminden Sağlanan Kişisel Fayda Bileşik Güvenilirlik-CR: 0,702; Açıklanan Ortalama Varyans- } \\
\text { AVE:0,875) }\end{array}$} \\
\hline $\begin{array}{l}\text { F1: Yöredeki turizm gelişiminden genel olarak ben de faydalanmaktayım. } \\
\text { F3: Yörede turizm olmazsa işlerim çok azalır. } \\
\text { F2: Turizm gelişimi, benim işimi olumlu yönde etkilemektedir. }\end{array}$ & $\begin{array}{l}0,841 \\
0,696 \\
0,742 \\
\end{array}$ & $\begin{array}{c}- \\
0,114 \\
0,089 \\
\end{array}$ & $\begin{array}{c}- \\
8,906 \\
11,047 \\
\end{array}$ \\
\hline \multicolumn{4}{|c|}{$\begin{array}{c}\text { Yerel Halkın Turizm Gelişimine İlişkin Memnuniyet Düzeyi (Bileşik Güvenilirlik-CR: 0,849; Açılanan } \\
\text { Ortalama Varyans-AVE:0,586) }\end{array}$} \\
\hline $\begin{array}{l}\text { M4: Turizmin yöremize sağladığı sosyal imkân ve olanaklardan memnunum. } \\
\text { M3: Turizmin yöremize sağladığı ekonomik gelişmelerden memnunum. } \\
\text { M1: Turizm ile birlikte gelişen kamu hizmetlerinden memnunum. } \\
\text { M2: Turizmin yaratmış olduğu çevresel değişim ve gelişimden memnunum. }\end{array}$ & $\begin{array}{l}0,751 \\
0,674 \\
0,706 \\
0,709\end{array}$ & $\begin{array}{c}- \\
0,076 \\
0,116 \\
0,118\end{array}$ & $\begin{array}{c}- \\
11,437 \\
8,393 \\
8,373\end{array}$ \\
\hline \multicolumn{4}{|c|}{$\begin{array}{c}\text { Yerel Halkın Turizm Gelişimine İlişkin Desteği (Bileşik Güvenilirlik-CR: 0,857; Açıklanan Ortalama Varyans- } \\
\text { AVE:0,602) }\end{array}$} \\
\hline D4: Yöredeki turizm gelişimini destekliyorum. & 0,686 & - & - \\
\hline D3: Yörede, t & 0,708 & 0,094 & 11,964 \\
\hline D2: Yörede, turizm yatırımları artarak devam etmelidir. & 0,812 & 0,147 & 9,268 \\
\hline D1: Turizm, toplumumuzun önemli bir parçası olmaya devam etmelidir. & 0,738 & 0,118 & 8,973 \\
\hline
\end{tabular}

* Regresyon katsayısı 1'e eşitlenmiştir. Katsayılar istatistiksel düzeyde anlamlıdır $p<0,01$; SRK: Standardize edilmiş regresyon katsay1s1, SH: Standart hata 
Ölçüm modeline ait AMOS programı çıktısı verileri yer alan Şekil 2'de boyutlar arasındaki korelasyonlar hakkında da bilgi alınabilmektedir. Ölçüm modeline göre "turizmin algılanan pozitif etkileri" boyutunun "turizmin gelişiminden sağlanan kişisel fayda sağlama" boyutu ile arasında 0,32, "turizmin algilanan negatif etkileri" boyutu ile arasında -0,40, "yerel halkın turizm gelişimine ilişkin memnuniyet düzeyi" boyutu ile arasında 0,39 ve "yerel halkın turizm gelişimine ilişkin desteği" boyutu ile arasında 0,41 olan ilişkiler test edilmiştir. Diğer yandan "turizmin gelişiminden sağlanan kişisel fayda" boyutunun "turizmin algılanan negatif etkileri" boyutu ile arasında $-0,15$; “yerel halkın turizm gelişimine ilişkin memnuniyeti düzeyi" boyutu ile arasında 0,49 ve "yerel halkın turizm gelişimine ilişkin desteği" boyutu ile arasında 0,20 olan ilişkiler elde edilmiştir. Benzer şekilde "turizmin algılanan negatif etkileri" boyutunun "yerel halkın turizm gelişimine ilişkin memnuniyeti düzeyi" boyutu ile arasında -0,60; "yerel halkın turizm gelişimine ilişkin desteği" boyutu ile arasında $-0,18$ olan ilişkiler test edilmiştir. Son olarak "yerel halkın turizm gelişimine ilişkin memnuniyeti düzeyi" boyutunun "yerel halkın turizm gelişimine ilişkin desteği" boyutu ile arasında 0,17 olan ilişkiler mevcuttur. Sonuç olarak, modelin "turizmin algılanan negatif etkileri" boyutunun diğer boyutlarla arasında negatif yönlü ilişkiler bulunurken "turizmin algilanan pozitif etkileri", "turizmin gelişiminden sağlanan kişisel fayda", "yerel halkın turizm gelişimine ilişkin memnuniyeti düzeyi" ve "yerel halkın turizm gelişimine ilişkin desteği" arasında pozitif yönde ve güçlü ilişkiler olduğu görülmektedir. Örneklem verilerinin doğrulayıcı faktör analizi ölçüm modeli Şekil 2' gösterilmiştir.

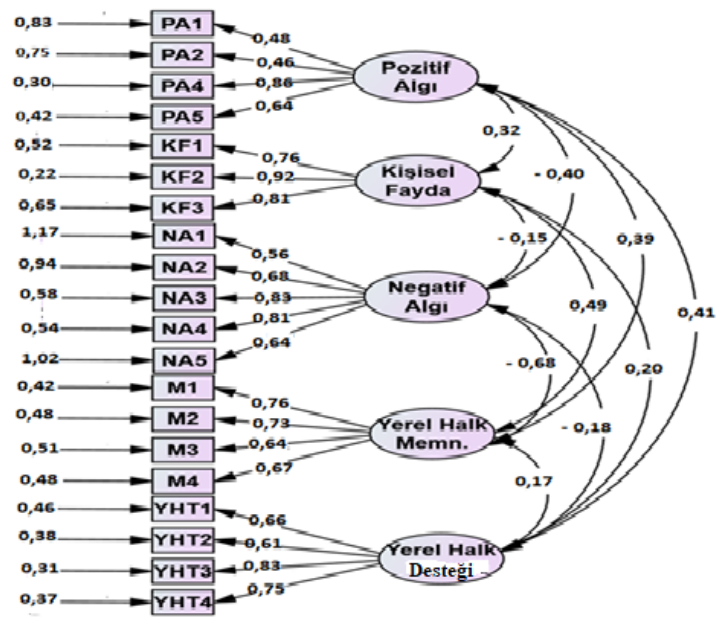

Şekil 1: Ölçüm Modeli

Tablo 5: Yapısal Modelin Uyum Değerleri

\begin{tabular}{|c|c|c|c|c|c|c|c|c|}
\hline $\begin{array}{c}\text { CMIN } \\
\mathbf{X}^{2}\end{array}$ & $\begin{array}{c}\text { (DF) } \\
\mathbf{S d}\end{array}$ & $\begin{array}{c}\text { CMIN/DF } \\
\mathbf{X}^{2} / \mathbf{s d}\end{array}$ & SRMR & GFI & AGFI & NFI & CFI & RMSEA \\
\hline 342,429 & 0,000 & 2,209 & 0,868 & 0,905 & 0,871 & 0,893 & 0,937 & 0,062 \\
\hline
\end{tabular}

Ölçüm modelinin doğrulanmasının ardından "turizmin algılanan pozitif etkileri", "turizmin gelişiminden kişisel fayda sağlama", "turizmin algılanan negatif etkileri" boyutlarının "turizm gelişimine ilişkin yerel halk memnuniyeti" ve "turizm gelişim desteğine ilişkin yerel halk tutumu" değişkenlerini yordayıp yordamadıklarını tespit etmek amacıyla yapısal modelin testine geçilmiştir. Yapısal modelin analizinde Yapısal Eşitlik Modellemesi (YEM) uygulanmıştır. 
Yapının yeterli uyum değerleri ürettiği görülmüş ve yapısal model doğrulanmıştır. Tablo 5, yapısal modelin uyum değerlerini göstermektedir.

\section{HİPOTEZLERINN SINANMASI}

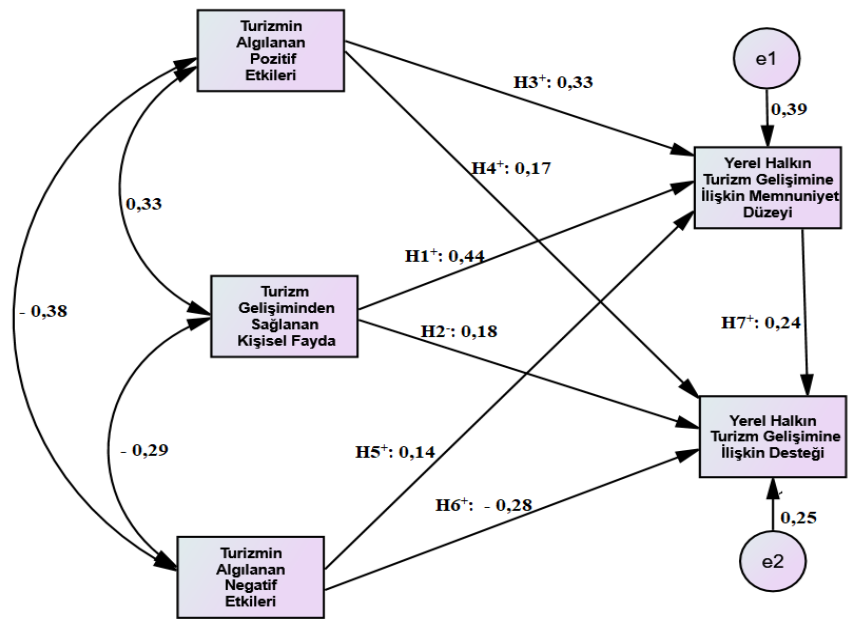

Şekil 2: Yol Analizi (Path Diyagramı)

Modele ilişkin yol katsayıları ve hipotez durumları Tablo 6'da sunulmuştur

Tablo 6: Yol Katsayıları ve Hipotez Sonuçları

\begin{tabular}{|l|l|l|l|l|l|}
\hline & $\begin{array}{l}\text { Standart } \\
\text { Tahmin } \\
\text { Değeri }\end{array}$ & $\begin{array}{l}\text { Standart } \\
\text { Hata }\end{array}$ & $\mathbf{t}$ & $\mathbf{P}$ & \multicolumn{1}{|c|}{$\begin{array}{c}\text { Hipotez } \\
\text { Sonucu }\end{array}$} \\
\hline YHTGIMD <-- TGSKF & 0,439 & 0,048 & 6,263 & $* * *$ & H1: KABUL \\
YHTGID<-- TGSKF & 0,138 & 0,039 & 1,929 & $\mathbf{0 , 0 5 4}$ & H2: RET \\
YHTGIMD <-- TAPE & 0,328 & 0,054 & 4,595 & $* * *$ & H3: KABUL \\
YHTGID <-- TAPE & 0,165 & 0,042 & 2,346 & 0,019 & H4: KABUL \\
TGIYHM <-- TANE & 0,176 & 0,059 & 2,539 & 0,011 & H5: KABUL \\
YHTGIMD <-- TANE & $-0,278$ & 0,048 & $-3,933$ & $* * *$ & H6: KABUL \\
YHTGID <-- TGIYHM & 0,237 & 0,064 & 2,926 & 0,003 & H7: KABUL \\
\hline
\end{tabular}

H1: Turizm gelişiminden sağlanan kişisel fayda boyutunun yerel halkın turizm gelişimine ilişkin memnuniyet düzeyi boyutu üzerinde anlamlı bir etkisi vardır.

Standardize edilmiş regresyon (Beta) katsayılarına göre turizm gelişiminden sağlanan kişisel fayda boyutunun $(\beta=0,439$ ve $p<0,05)$ yerel halkın turizm gelişimine ilişkin memnuniyet düzeyi boyutu üzerinde anlamlı etkisi $(t=6,263)$ vardır. Buna dayanarak H1 hipotezi kabul edilmiştir. Diğer bir ifade ile yerel halkın turizm gelişimine ilişkin memnuniyet düzeyi boyutunun yaklaşık olarak \%44'ü turizm gelişiminden sağlanan kişisel fayda boyutu tarafından açıklanmaktadır. Örneklemi oluşturan katılımcıların, turizm gelişiminden sağlanan kişisel fayda boyutunda 
meydana gelebilecek 1 birimlik değişiklik, diğer bağımsız değişkenler turizmin algılanan pozitif etkileri boyutu ve turizmin algılanan negatif etkileri boyutu sabit kalmak şartıyla yerel halkın turizm gelişimine ilişkin memnuniyet düzeyi boyutu üzerinde 0,439 birimlik atı̧sa neden olmaktadır.

H2: Turizm gelişiminden sağlanan kişisel fayda boyutunun yerel halkın turizm gelişimine ilişkin desteği boyutu üzerinde anlamlı bir etkisi vardır.

Standardize edilmiş regresyon (Beta) katsayılarına göre turizm gelişiminden sağlanan kişisel fayda boyutunun $(\beta=0,138$ ve $p=0,054>0,05)$ yerel halkın turizm gelişimine ilişkin memnuniyet düzeyi boyutu üzerinde anlamlı etkisi yoktur. Buna dayanarak $\mathrm{H} 2$ hipotezi reddedilmiştir.

H3: Turizmin algılanan pozitif etkileri boyutunun yerel halkın turizm gelişimine ilişkin memnuniyet düzeyi boyutu üzerinde anlamlı bir etkisi vardır.

Standardize edilmiş regresyon (Beta) turizmin algılanan pozitif etkileri boyutunun $(\beta=0,328$ ve $\mathrm{p}<0,05)$ yerel halkın turizm gelişimine ilişkin memnuniyet düzeyi boyutu üzerinde anlamlı etkisi $(t=4,595)$ vardır. Buna dayanarak H3 hipotezi kabul edilmiştir. Diğer bir ifade ile yerel halkın turizm gelişimine ilişkin memnuniyet düzeyi boyutunun yaklaşık olarak \%33'ü turizmin algılanan pozitif etkileri boyutu tarafından açıklanmaktadır. Örneklemi oluşturan katılımcıların turizmin algılanan pozitif etkileri boyutunda meydana gelebilecek 1 birimlik değişiklik, diğer bağımsız değişkenler turizm gelişiminden sağlanan kişisel fayda boyutu ve turizmin algılanan negatif etkileri boyutu sabit kalmak şartıyla yerel halkın turizm gelişimine ilişkin memnuniyet düzeyi boyutu üzerinde 0,328 birimlik artışa neden olmaktadır.

$\mathbf{H}_{4}$ : Turizmin algllanan pozitif etkileri boyutunun yerel halkın turizm gelişimine ilişkin desteği boyutu üzerinde anlaml etkisi vardır.

Standardize edilmiş regresyon (Beta) turizmin algilanan pozitif etkileri boyutunun $(\beta=0,165$ ve $p<0,05)$ yerel halkın turizm gelişimine ilişkin desteği boyutu üzerinde anlamlı etkisi $(t=2,346)$ vardır. Buna dayanarak H4 hipotezi kabul edilmiştir. Diğer bir ifade ile yerel halkın turizm gelişimine ilişkin desteği boyutunun yaklaşık olarak \%17'si turizmin algılanan pozitif etkileri boyutu tarafından açıklanmaktadır. Örneklemi oluşturan katılımcıların turizmin algılanan pozitif etkileri boyutunda meydana gelebilecek 1 birimlik değişiklik, diğer bağımsız değişkenler turizm gelişiminden sağlanan kişisel fayda boyutu ve turizmin algılanan negatif etkileri boyutu sabit kalmak şartıyla yerel halkın turizm gelişimine ilişkin desteği boyutu üzerinde 0,165 birimlik artışa neden olmaktadır.

H5: Turizmin algılanan negatif etkileri boyutunun yerel halkın turizm gelişimine ilişkin memnuniyet düzeyi boyutu üzerinde anlamlı bir etkisi vardır.

Standardize edilmiş regresyon (Beta) katsayılarına göre turizmin algılanan negatif etkileri boyutunun $(\beta=0,176$ ve $p<0,05)$ yerel halkın turizm gelişimine ilişkin memnuniyet düzeyi boyutu üzerinde anlamlı etkisi $(t=2,539)$ vardır. Buna dayanarak H5 hipotezi kabul edilmiştir. Diğer bir ifade ile yerel halkın turizm gelişimine ilişkin memnuniyet düzeyi boyutunun yaklaşık olarak $\% 18$ 'i turizmin algılanan negatif etkileri boyutu tarafından açılanmaktadır. Örneklemi oluşturan katılımcıların, turizmin algılanan negatif etkileri boyutunda meydana gelebilecek 1 birimlik değişiklik, diğer bağımsız değişkenler turizmin algılanan pozitif etkileri boyutu ve turizm gelişiminden sağlanan kişisel fayda boyutu sabit kalmak şartıyla yerel halkın turizm gelişimine ilişkin memnuniyet düzeyi boyutu üzerinde 0,176 birimlik artışa neden olmaktadır.

H6: Turizmin algılanan negatif etkileri boyutunun, yerel halkın turizm gelişim desteğine ilişkin desteği boyutu üzerinde anlamlı bir etkisi vardır. 
Standardize edilmiş regresyon (Beta) turizmin algilanan negatif etkileri boyutunun ( $\beta=0,278$ ve $p<0,05)$ yerel halkın turizm gelişimine ilişkin desteği boyutu üzerinde anlamlı etkisi $(t=3,933)$ vardır. Buna dayanarak H6 hipotezi kabul edilmiştir. Diğer bir ifade ile yerel halkın turizm gelişimine ilişkin desteği boyutunun yaklaşık olarak \%28'i turizmin algılanan negatif etkileri boyutu tarafından açıklanmaktadır. Örneklemi oluşturan katılımcıların turizmin algılanan negatif etkileri boyutunda meydana gelebilecek 1 birimlik değişiklik, diğer bağımsız değişkenler turizm gelişiminden sağlanan kişisel fayda boyutu ve turizmin algılanan pozitif etkileri boyutu sabit kalmak şartıyla yerel halkın turizm gelişimine ilişkin desteği boyutu üzerinde 0,278 birimlik artışa neden olmaktadır.

H: Yerel halkın turizm gelişimine ilişkin memnuniyet düzeyi boyutunun, yerel halkın turizm gelişimine ilişkin desteği boyutu üzerinde anlamlı bir etkisi vardır.

Standardize edilmiş regresyon (Beta) yerel halkın turizm gelişimine ilişkin memnuniyet düzeyi boyutunun $(\beta=0,237$ ve $p<0,05)$, yerel halkın turizm gelişimine ilişkin desteği boyutu üzerinde anlamlı etkisi $(t=2,926)$ vardır. Buna dayanarak $H 7$ hipotezi kabul edilmiştir. Diğer bir ifade ile yerel halkın turizm gelişimine ilişkin desteği boyutunun yaklaşık olarak \%24'ü yerel halkın turizm gelişimine ilişkin memnuniyet düzeyi boyutu tarafından açıklanmaktadır. Örneklemi oluşturan katılımcıların yerel halkın turizm gelişimine ilişkin memnuniyet düzeyi boyutunda meydana gelebilecek 1 birimlik değişiklik yerel halkın turizm gelişimine ilişkin desteği üzerinde 0,237 birimlik artışa neden olmaktadır.

\section{TARTIŞMA ve SONUÇ}

Bodrum yerel halkının ilçedeki turizm gelişimine karşın edindikleri tutumun belirlenmesi amaç edinilen bu çalışmada, turizm gelişim boyutları arasındaki ilişki incelenmiştir. Açımlayıcı faktör analizi yapılarak boyutları oluşturan ifadelerin geçerlilik ve güvenilirlik oranları belirlenmiştir. Açımlayıcı faktör analizi sonucuna göre, araştırma modelinin 5 gizil değişkeni bulunmaktadır. Modelin 5 gizil değişkeninden ikisi endojen-gizil değişken, diğer üçü egzojen-gizil değişkenlerdir. Modeldeki endojen-gizil değişkenler (bağımlı değişken) "Yerel Halk Memnuniyeti" ve "Yerel Halk Tutumu" değişkenleridir. İki endojen-gizil değişkene etki eden egzojen-gizil değişkenler ise "Pozitif Alg1", "Kişisel Fayda", "Negatif Alg1" değişkenleridir.

Yapısal eşitlik modellemesinde negatif algı dışında diğer gizil değişkenler arasındaki ilişkilerde pozitif yönlü ve anlamlı ilişkiler olduğu sonucuna varılmıştır. Negatif algı değişkeni ile yerel halkın turizm gelişimine ilişkin memnuniyet düzeyi arasında pozitif yönlü bir ilişki söz konusudur. Buna rağmen negatif algı değişkeni ile yerel halkın turizm gelişimine ilişkin desteği arasında negatif yönlü ilişki mevcuttur. Turizm gelişimine ilişkin memnunluk düzeyi yüksekken, turizm gelişimine destek verilmeyişi ancak, yerel halk için mecbur kalınan bir seçenek olması ile yorumlanabilir. Analiz sonuçlarına göre Bodrum yerel halkı, turizmin çevresel, kültürel, sosyal gibi olumsuz etkilerine karşı bir kayıtsızlık içerisindedirler. Yerel halk tarafından göz ardı edilen bu negatif etkiler, turizm gelişim aşamalarında yol almak açısından önemli bir eksikliktir. Çünkü bu sonuç, yerel halkın kendini turizmin bir parçası olarak görmediğinin göstergesidir. Literatür taramasında birçok araştırmacı, yerel halkı turizm gelişim sürecine dâhil etmek, onların bu konudaki görüş ve önerilerini almak, fikir alışverişinde bulunmak ve gelecekteki turizm gelişimini teşvik yönünde yerel halkın karar merkezlerini etkileyebilmesi ve kendini turizmin bir parçası olarak hissetmeleri açısından önem arz ettiği sonucuna ulaşmıştırlar. Yerel halkın fikir ve görüşlerinin alınmadığı durumlarda turizm gelişiminden ve turizm gelirlerinin artırılmasından söz etmek mümkün değildir. 
Sonuç olarak turizm gelişim stratejilerinin oluşturulması, uygulanması ve sürdürülebilirliğinin sağlanması açısından yerel halkın görüş ve önerileri önem arz etmektedir. Destinasyon yöneticilerinin turizm gelişim süreçlerini belirlemesi ve yerel halkın fikir ve görüşlerine aralıklı olarak başvurmaları gerekir. Yerel halkın görüşlerinin alınmadığı durumlarda, turizm gelişimi için yapılan plan ve uygulamalar başarısızlıkla sonuçlanır.

Turizmin gelişiminde turizmin olumlu ve olumsuz etkilerinin belirlenmesinde temel alınan unsur destinasyonun taşıma kapasitesidir. Taşıma kapasitesi bir alanın normal kullanımı için elverişli ziyaretçi seviyesini ifade ederken, gelen ziyaretçilerden ev sahibi yerel halkın duyduğu hoşnutsuzluk seviyesi de sosyal taşıma kapasitesi olarak nitelendirilir. Doxey'in rahatsızlık endeksi kapsamında Bodrum yerel halkının turizme karşı sosyal taşıma kapasitesi "kayıtsızlık" düzeyindedir. Destinasyona gelen turistin verdiği olumlu ya da olumsuz etkiler karşısında halk tepkisiz durumdadır. Buradan çıkan sonuç, maddi getirinden dolayı Bodrum yerel halkının turizmi mecbur kalınan bir faaliyet olarak görülmesidir. Turizm gelişiminde kayıtsız bir tavır içinde olan yerel halk, rahatsızlığını dile getiren bir döneme girme aşamasındadır. Bu da Doxey'in Rahatsızlık Endeksinde "rahatsızlık" düzeyi olarak belirtilmektedir. Destinasyonun yaşam devrelerinde gerileme dönemine geçişte, yerel halkın turizme ve turiste karşı tutumu belirleyici konumdadır. Bu sebepten ötürü destinasyon yöneticilerinin ve turizm planlaması yapanların yerel halkın fikir ve görüşlerine sık sık başvurması gerekmektedir. Bu çalışma ile yöneticilere, turizm planlama stratejileri için önemli çıkarımlar sunulmuştur. Bu tür çalışmalar, yerel halk tutumunun belirlenmesi için ara ara yapılmalı ve sonuçlar dikkatlice irdelenmelidir. Belirli aralıklarla yapılan tutum çalışmaları, yerel halkın turizm gelişiminde söz sahibi olduklarını bilmeleri açısından önemli olup, turizm faaliyetlerinin şekillenmesinde teşvik edici unsur özelliğindedir.

\section{KAYNAKÇA}

Allen, L., Long, P.T., Perdue R.R and Keiselbach, S. (1988). The Impact of Tourism Development on Residents' Perception of Community Life. Journal of Travel Research, 27(1):16-21.

Allen, L. R., Hafer, H. R., Long, R. and Perdue, R.R. (1993) Rural Residents' Attitudes Toward Recreation and Tourism Development, Journal of Travel Research, 31 (4): 27-33.

Avcı, N. (2007). Turizmde Taşıma Kapasitesinin Önemi. Ege Akademik Bakış, 7(2), 493-509. (Akt: Avcıkurt, C. (2009). Turizm Sosyolojisi: Genel ve Yapısal Yaklaşım. (3. Baskı), Ankara: Detay Yayincilik.

Avcıkurt, C., (2003). Turizm Sosyolojisi: Turist, Yerel Halk Etkileşimi. Ankara: Detay Yayıncılık Detay Yayıncilık.

Büyüköztürk, Şener. (2002). Faktör Analizi: Temel Kavramlar ve Ölçek Geliştirmede Kullanımı. Kuram ve Uygulamada Eğitim Yönetim Dergisi, 32, 470-483.

Can, E. (2013). Turizm Destinasyonlarında Sürdürülebilir Turizmin Sürdürülebilir Rekabet Açısından Değerlendirilmesi. İstanbul Journal of Social Sciences Summer, 4. 23-40.

Child, D. (2006). The essentials of factor analysis. Continuum, London.

Çalışkan, U. ve Özer, Ö (2014). Yerel Halkın Turizme Karşı Tutumu: Kuşadası İlçesinde Karşılaştırmalı Bir Uygulama. Dokuz Eylül Üniversitesi İ̧̧letme Fakültesi Dergisi 15(2), 117-133.

Davis, D., Allen, J. and Cosenza, R.M., (1988). Segmenting Local Residents by their Attitudes, Interests, and Opinions toward Tourists. Journal of Travel Research, 27 (2), 2-8. 
Doxey, G.V., (1975). A Causation Theory of Visitor-Resident Irritants, Methodology, and Research Inferences. Sixth Annual Conference Proceedings of the Travel Research Association. San Diego, CA: Travel and Tourism Research Association, 195-198.

Duran, E. (2013). Yerel halkın sürdürülebilir turizm gelişimine yönelik tutumları: Bozcaada örneği. UHBAB Uluslararası Hakemli Beşeri ve Akademik Bilimler Dergisi. 2 (3), 76-93.

Duran, E. ve Özkul, E. (2012) Yerel Halkın Turizm Gelişimine Yönelik Tutumları: Akçakoca Örneği Üzerinden Bir Yapısal Model. International Journal of Human Sciences, 9(2): 500-520.

Ekici, R. ve Çizel, B. (2014). Yerel Halkın Turizm Gelişimi Desteğine İlişkin Tutumlarının Destinasyonların Gelişme Düzeylerine Göre Farklılıkları. Seyahat ve Otel İşletmeciliğgi Dergisi, 11(3), 73-87.

Emekli, G., (2005). Avrupa Birliği'nde Turizm Politikaları ve Türkiye'de Kültürel Turizm. Ege Coğrafya Dergisi. Sayı:14, İzmir. 99-107.

Getz, D. (1994) Residents' Attitudes Toward Tourism: A Longitudinal Study in Spey Valley, Scotland, Tourism Management, 15 (4), 247-258.

Gunn, C, A., (1988). Tourism Planning. (2. Basım). New York, Taylor \&Francis.

Hall, C. M. (2001). Geography of Tourism \& Recreation: Environment. Place \& Space, Routrege, Florence, USA.

İçöz, O., Var, T. ve İlhan, İ. (2002). Turizm Pazarlaması. Ankara, Turhan Kitabevi.

Jurowski, C., Uysal, M. and Williams, D.R. (1997). A Theorical Analysis of Host Community Resident Reaction to Tourism. Journal of Travel Research, 34 (2):3-11.

Kahraman, N. ve Türkay, O. (2006). Turizm ve Çevre. (2. Baskı). Ankara, Detay Yayıncllı.

Knopp, T. B. (1980). Tourism the Local Interests and The Function Public Lands. (Editör) D.E. Hawkins, E.L. Shafer, and J. M. Rovelstad: Tourism Planning and Development içinde Washington D.C.: George Washington University, ss.225-37.

Ko, D.W. and Stewart, W. P. (2002) A Structural Equation Model of Residents Attitudes for Tourism Development, Tourism Management, 23, 521-530.

Long, P. T. and S.L. Richardson (1989), Integrating Recreation and Tourism Development in Small Winter Cities. Leisure Today, 26, 58-61.

Maddox, R.N. (1985). Measuring Satisfaction with Tourism. Journal of Travel Research, 23 (Winter):2-5.

Rızaoğlı, B. ve Tanrıverdi, A. (1997). Yerel Toplumsal Duyarlılığın Bir Ölçüsü Olarak Turizmin Toplumsal Taşıma Kapasitesi. Anatolia Turizm Araştırmaları Dergisi, 8(1), 52-58.

Sekhar, N. U., 2003. Local People's Attitudes Towards Conservation and Wildlife Tourism Around Sariska Tiger Reserve, Journal of Environmental Management 69, India.

Sowman, Marle S. (1987). A procedure for Assessing Recreational Carrying Capacity of Coastal Resort Areas. Landscape and Urban Planning, 14 (1), 332-333.

Tavşancıl, E. (2006). Tutumların Ölçülmesi ve Spss ile Veri Analizi, Ankara, Nobel Yayınevi.

Vargas-Sanchez, A., Plaza-Mejia, M.A. and Porras-Bueno, N. (2009) Residents' Attitudes Towards Tourism Development in the Spanish Province of Huelva, Narodnostopanski Arhiv, International Edition, 31-63. 
Vesey, C.M. and Dimanche, F., (2000). Urban Residents' Perceptions of Tourism and Its Impacts, Unpublished Manuscript, University of New Orleans, LA.

Yoon, Y., Gürsoy, D. and Chen, J.S. (2001). Validating a Tourism Development Theory with Structural Equation Modeling. Tourism Management, 22, 363-372.

Zhong, L., Deng, J., Song, Z. and Ding, P. (2011). Research on Environmental Impacts of Tourism in China: Progress and Prospec. Journal of Environmental Management, 92, 2972-2983. 